\title{
IL-32 promotes breast cancer cell growth and invasiveness
}

\author{
SHOUMAN WANG, FEIYU CHEN and LILI TANG \\ Department of Breast Surgery, Xiangya Hospital, Central South University, Changsha, Hunan 410008, P.R. China
}

Received March 25, 2014; Accepted September 30, 2014

DOI: 10.3892/ol.2014.2641

\begin{abstract}
Interleukin (IL)-32 is a newly identified cytokine in humans and primates. It has been established that IL-32 may antagonize cancer growth. However, to the best of our knowledge, the direct effect of IL-32 on breast cancer cell growth has not yet been investigated. In addition, rodents lack the expression of IL-32; hence, the effects of IL-32 on breast cancer xenografts in nude mice have not been studied. The present study aimed to examine the potential regulatory effects of IL-32 on breast cancer cells in nude mice. The effects of IL-32 on tumor cell growth in cell cuture and a tumor xenograft model were investigated, as well as the effects of IL-32 on apoptosis. The effects of IL-32 on cell proliferation and apoptosis were investigated by MTT assay and TUNEL staining, respectively. The results revealed that IL-32 increases the proliferation rate of cancer cells and decreases the rate of apoptosis, In addition, IL-32 was found to enhance the growth of tumor xenografts in vivo. In summary, IL-32 may represent a useful therapeutic target for human breast cancer.
\end{abstract}

\section{Introduction}

Interleukin (IL)-32, or NK4, is a novel cytokine which was originally isolated from activated $\mathrm{T}$ cells. Treatment of lymphocytes with IL-32 may induce the expression of different cytokines, including tumor necrosis factor (TNF)- $\alpha$ or IL-8, which have been found to be involved in multiple inflammatory processes and cancer progression. Notably, a gene homolog of IL-32 was not found in rodents, hence previous study of this cytokine has been limited to cell lines in vitro.

Breast cancer represents a malignant cancer with serious consequences for the female population (1-3). There have been $>400,000$ breast cancer related mortalities per year in the pastdecade (4-6). Early diagnosis represents the most important factor for successful treatment in the early stages;

Correspondence to: Professor Lili Tang, Department of Breast Surgery, Xiangya Hospital, Central South University, 87 Xiangya Road, Changsha, Hunan 410008, P.R. China

E-mail: tanglili_breast@163.com

Key words: breast cancer, inflammation, interleukin-32 while the prognosis for patients diagnosed in the later stages is notably poorer $(1,2,7,8)$. The current efforts in treating breast cancer focus on multiple signaling pathways, which are involved in tumor formation, growth and metastasis (9-11).

The present study aimed to examine the potential effects of IL-32 on the development and progression of breast cancer. Cultured breast cancer cell lines and a tumor graft model were employed to assist in understanding how this inflammatory cytokine contributes to the growth and survival of tumor cells in vitro and in vivo.

\section{Materials and methods}

Ethics. This animal study has been approved by the Animal Research Ethics Committee of Xiangya Hospital, Central South University (Changsha, China). All procedures requiring animal manipulation followed the animal experiment guidelines of the Animal Center of Central South University. The approval number of this project is CSU3009-2011-BC009.

Agents and cell culture. IL-32 was obtained from He'nuo Biotech (Changsha, China). The MCF-7 cell line was purchased from Gongji Biotech (Shanghai, China), and cultured in Dulbecco's modified Eagle's medium (DMEM; Invitrogen Life Technologies, Carlsbad, CA, USA) with $100 \mathrm{mg} / \mathrm{ml}$ penicillin (Sigma Corporation, Shanghai, China) and $10 \%$ fetal bovine serum (Sigma Corporation) at $37^{\circ} \mathrm{C}$ in $5 \% \mathrm{CO}_{2}$. For $12 \mathrm{~h}$ glucose withdrawl, the glucose was removed from the medium for $12 \mathrm{~h}$, with all other components maintained. At the end of the withdrawl period, the glucose-containing medium was used again.

3-(4, 5-dimethylthiazol-2-yl)-2,5-diphenyltetrazolium bromide (MTT) assay. In order to examine the cell viability, an MTT assay was performed. A total of 6,000 cells were seeded into 96 -well plates and cultured for 24 or $48 \mathrm{~h}$ in the presence of IL-32 at 10, 100 or $500 \mathrm{ng} / \mathrm{ml}$.

Following incubation for 24 or $48 \mathrm{~h}, 150 \mu 15 \mathrm{mg} / \mathrm{ml}$ MTT solution was added for $2 \mathrm{~h}$. The supernatant was removed following centrifugation at 5,000 $\mathrm{xg}$ for $2 \mathrm{~min}$ at $4^{\circ} \mathrm{C}$ and $150 \mu \mathrm{l}$ DMSO was added to each well for absorbance reading at a wavelength of $490 \mathrm{~nm}$ using a plate reader (Bio-Rad 680; Bio-Rad Laboratories, Shanghai, China). The assay was repeated six times.

Caspase-3 assay and TUNEL staining. In order to measure the levels of cell apoptosis, the Caspase-3 activity assay (Roche 
Table I. Effect of interleukin (IL)-32 on cell proliferation.

\begin{tabular}{|c|c|c|c|c|c|c|c|c|}
\hline & \multicolumn{4}{|c|}{$24 \mathrm{~h}$} & \multicolumn{4}{|c|}{$48 \mathrm{~h}$} \\
\hline & \multirow[b]{2}{*}{ Control } & \multicolumn{3}{|c|}{ IL-32 } & \multirow[b]{2}{*}{ Control } & \multicolumn{3}{|c|}{ IL-32 } \\
\hline & & $10 \mathrm{ng} / \mathrm{ml}$ & $100 \mathrm{ng} / \mathrm{ml}$ & $500 \mathrm{ng} / \mathrm{ml}$ & & $10 \mathrm{ng} / \mathrm{ml}$ & $100 \mathrm{ng} / \mathrm{ml}$ & $500 \mathrm{ng} / \mathrm{ml}$ \\
\hline Viable cells $(\%)$ & $\begin{array}{c}100 \\
\text { (normalized) }\end{array}$ & $106.2 \pm 4.4$ & $130.1 \pm 7.2^{\mathrm{b}}$ & $144.6 \pm 5.3^{\mathrm{b}}$ & $\begin{array}{c}100 \\
\text { (normalized) }\end{array}$ & $108.9 \pm 5.3^{\mathrm{a}}$ & $134.7 \pm 7.6^{\mathrm{b}}$ & $157.2 \pm 7.4^{\mathrm{b}}$ \\
\hline
\end{tabular}

${ }^{\mathrm{a}} \mathrm{P}<0.05$ and ${ }^{\mathrm{b}} \mathrm{P}<0.01$, compared with the control group.

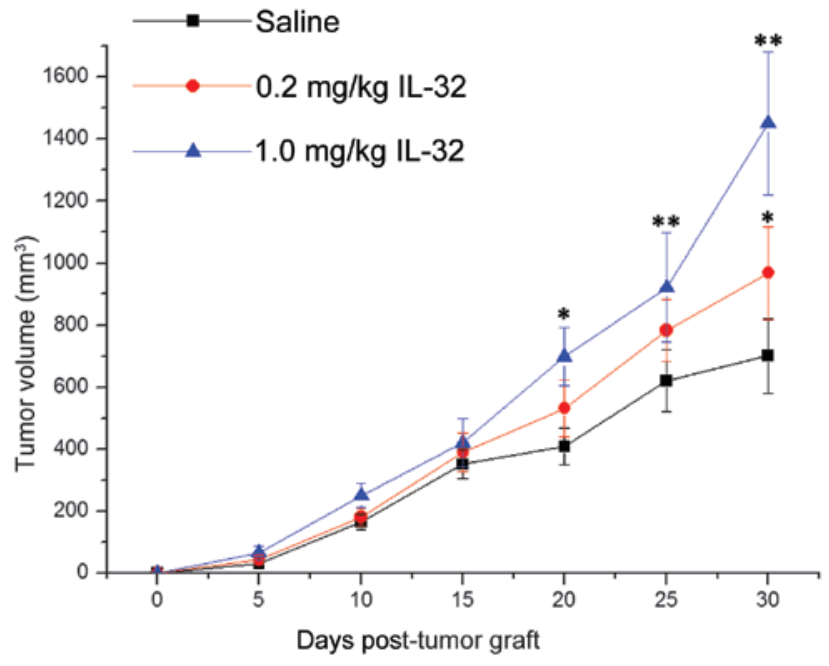

Figure 1. Interleukin (IL)-32 enhances the growth of breast cancer cell xenografts in nude mice. ${ }^{*} \mathrm{P}<0.05$ and ${ }^{* *} \mathrm{P}<0.01$, compared with the control group.

Diagnostics, Indianapolis, IN, USA) was used. Additionally, the TUNEL kit (Roche Diagnostics) was adopted for staining and cell counting, according to the manufacturer's instructions. Following labeling with fluorescein isothiocyanate, the positive cells were counted under a Zeiss Axio Imager 2 microscope (Zeiss, Oberkochen, Germany; magnification, $\mathrm{x} 40$; 10 sites from each experiment, repeated 3 times).

Animal study. For tumor graft formation, the MDA-MB-231 estrogen-independent breast cancer cell line (Gongji Biotech, Shanghai, China) was employed as previously described (12). In total, $2 \times 10^{7}$ MDA-MB-231 cells were separated with $170 \mu 1$ DMEM medium and inoculated subcutaneously into the right flanks of 48 nude mice (weight, 20-30 g; age, 2 months; Animal Research Center, Xiangya Hospital).

For the drug treatment, 0.2 or $1 \mathrm{mg} / \mathrm{kg}$ IL-32 was administrated via careful intraperitoneal (i.p.) injection every two days. A total of 16 mice were treated with saline (control group), 16 were treated with $0.2 \mathrm{mg} / \mathrm{kg}$ IL-32 and 16 were treated with $1 \mathrm{mg} / \mathrm{kg}$ IL-32. An insulin injection syringe (total volume, $0.5 \mathrm{ml}$; Xiangya Hospital) was used to prevent any harm caused by normal syringe needles.

Tumor size was measured every 5 days for 30 days and the volume was calculated as follows: Volume $=0.5$ multiplied by length multiplied by width multiplied by width. On day 30 , the mice were sacrificed by $\mathrm{CO}_{2}$ inhalation and the tumors were harvested and fixed in 10\% formalin. The tumors were then cut into $10 \mu \mathrm{m}$ sections in a Cryostat (Leica CM 3050S; Leica Microsystems, Wetzlar, Germany). A TUNEL in situ cell deah dection kit (Roche Diagostics) was used for staining and cell counting, according to the manufacturer's instructions. Briefly, the cells were incubated with DNA-labeling solution for $60 \mathrm{~min}$ at $37^{\circ} \mathrm{C}$, then washed three times with rinse buffer prior to incubation with the antibody-staining solution for $30 \mathrm{~min}$ at room temperature in the dark.

Statistics. Data are presented as the mean \pm standard deviation and were analyzed using SPSS software, version 11.0 (SPSS, Inc., Chicago, IL, USA). A t-test and analysis of variance were used to compare differences between the groups. $\mathrm{P}<0.05$ was considered to indicate a statistically significant difference.

\section{Results}

IL-32 increases cell proliferation. The results demonstrated that IL-32 treatment reduced the cell numbers compared with the untreated cells, as detected by light absorbance. After 24 or $48 \mathrm{~h}$, the number of viable cells significantly increased following 100 or $500 \mathrm{ng} / \mathrm{ml}$ IL-32 treatment $(\mathrm{P}<0.01)$. In addition, this association appeared to be concentration-dependent (Table I).

$I L-32$ decreases the levels of cancer cell apoptosis in vitro following glucose withdrawal. Given that IL-32 treatment increased cell proliferation, the subsequent step was to investigate whether this treatment leads to a reduction in cell apoptosis after $12 \mathrm{~h}$ glucose withdrawal. Using TUNEL staining, the rate of apoptosis in the control group was revealed to be $56.7 \pm 8.9 \%$, while those in the 10,100 and $500 \mathrm{ng} / \mathrm{ml} \mathrm{IL-32-treated}$ groups were $44.2 \pm 6.7 \%(\mathrm{P}<0.01), 37.7 \pm 6.9 \%(\mathrm{P}<0.01)$ and $34.3 \pm 5.1 \%(\mathrm{P}<0.01)$ at the $24 \mathrm{~h}$ time point $(12 \mathrm{~h}$ following the induction of glucose withdrawal).

$I L-32$ increases the growth of tumor xenografts. Following the results of the cell proliferation assay, it was investigated whether IL-32 contributed to tumor growth in vivo. It was revealed that IL-32 treatment at $0.2 \mathrm{mg} / \mathrm{kg}$ and $1 \mathrm{mg} / \mathrm{kg}$ increased the tumor graft growth compared with treatment with saline only (Fig. 1). 


\section{Discussion}

To the best of our knowledge, the current study is the first to characterize the effects of IL-32 on cancer cells directly; specifically, on breast cancer cells. IL-32 showed cancer-promoting effects in vitro and in vivo. These results are consistent with previous studies showing the involvement of IL-32 in response to certain inflammatory processes (13-15). IL-32 may act as an intracellular controller, determining the cell survival and death (13). Indeed, the current study found that in culture IL-32 seems to enhance survival of breast cancer cells in a glucose-withdrawn environment. Additionally, IL-32 increased the total number of total, as revealed by increased cell proliferation, which is consistent with a previous finding showing that IL-32 induces the expansion of hematopoietic progenitor cells (16).

It should be noted that in a previous study, the IL-32 $\gamma$ variant has been shown to inhibit cancer growth by silencing the NF- $\kappa \mathrm{B}$ and STAT3 signaling pathways (17). In the aforementioned study, colon cancer cells were directly transfected with IL-32 $\gamma$, prior to transplantation in nude mice. The present study used an i.p. injection of IL-32, therefore systemic IL-32 may trigger additional effects, for example the recruitment of other inflammatory signaling pathways. We hypothesized that since cancer tissues have an increased expression of IL-32, this indicated the potential involvement of this cytokine in cancer growth, for example in pancreatic cancer $(18,19)$.

In conclusion, the results of the current study suggest that IL-32 exerts modulatory effects on the growth and survival of breast cancer cells. Therefore IL-32 may be a novel therapeutic target for breast cancer, and potentially other types of cancer as well. Future studies, which investigate the combination of IL-32 silencing and chemotherapy drugs for breast cancer treatment may be useful.

\section{References}

1. Gelao L, Criscitiello C, Fumagalli L, et al: Tumour dormancy and clinical implications in breast cancer. Ecancermedicalscience 7: $320,2013$.
2. Ligibel JA and Strickler HD: Obesity and its impact on breast cancer: tumor incidence, recurrence, survival, and possible interventions. Am Soc Clin Oncol Educ Book 2013: 52-59, 2013.

3. Cooney MA, Culleton-Quinn E and Stokes E: Current knowledge of pain after breast cancer treatment: a systematic review. Pain Manag Nurs 14: 110-123, 2013.

4. Makarem N, Chandran U, Bandera EV and Parekh N: Dietary fat in breast cancer survival. Annu Rev Nutr 33: 319-348, 2013.

5. Despas F, Roche H and Laurent G: Anticancer drug adherence. Bull Cancer 100: 473-484, 2013 (In French).

6. Khan KH, Yap TA, Yan L and Cunningham D: Targeting the PI3K-AKT-mTOR signaling network in cancer. Chin J Cancer 32: 253-265, 2013.

7. Ma X, Liu L, Nie W, et al: Prognostic role of caveolin in breast cancer: a meta-analysis. Breast 22: 462-469, 2013.

8. Corben AD: Pathology of invasive breast disease. Surg Clin North Am 93: 363-392, 2013.

9. Chen WX, Hu Q, Qiu MT, et al: miR-221/222: promising biomarkers for breast cancer. Tumour Biol 34: 1361-1370, 2013.

10. O'Toole SA, Beith JM, Millar EK, et al: Therapeutic targets in triple negative breast cancer. J Clin Pathol 66: 530-542, 2013.

11. Zhang X, Li XR and Zhang J: Current status and future perspectives of PI3K and mTOR inhibitor as anticancer drugs in breast cancer. Curr Cancer Drug Targets 13: 175-187, 2013.

12. Warin R, Xiao D, Arlotti JA, Bommareddy A and Singh SV: Inhibition of human breast cancer xenograft growth by cruciferous vegetable constituent benzyl isothiocyanate. Mol Carcinog 49: 500-507, 2010.

13. Heinhuis B, Netea MG, van den Berg WB, Dinarello CA and Joosten LA: Interleukin-32: a predominantly intracellular proinflammatory mediator that controls cell activation and cell death. Cytokine 60: 321-327, 2012.

14. Soyka MB, Treis A, Eiwegger T, et al: Regulation and expression of IL-32 in chronic rhinosinusitis. Allergy 67: 790-798, 2012.

15. Meyer N, Christoph J, Makrinioti H, et al: Inhibition of angiogenesis by IL-32: possible role in asthma. J Allergy Clin Immunol 129: 964-973.e7, 2012.

16. Moldenhauer A, Futschik M, Lu H, et al: Interleukin 32 promotes hematopoietic progenitor expansion and attenuates bone marrow cytotoxicity. Eur J Immunol 41: 1774-1786, 2011.

17. Oh JH, Cho MC, Kim JH, et al: IL-32gamma inhibits cancer cell growth through inactivation of NF-kappaB and STAT3 signals. Oncogene 30: 3345-33598 2011.

18. Felaco P, Castellani ML, De Lutiis MA, et al: IL-32: a newly-discovered proinflammatory cytokine. J Biol Regul Homeost Agents 23: 141-147, 2009.

19. Nishida A, Andoh A, Inatomi O and Fujiyama Y: Interleukin-32 expression in the pancreas. J Biol Chem 284: 17868-178766, 2009. 